Research Article

\title{
Post-harvest practices and loss assessment in tomato (Solanum lycopersicum L.) in Kathmandu, Nepal
}

\author{
Injila Tiwari ${ }^{1}$, Kabita Kumari Shah ${ }^{2 *}$, Subina Tripathi ${ }^{1}$, Bindu Modi ${ }^{3}$, Jiban Shrestha ${ }^{4}$, Hari \\ Prasad Pandey ${ }^{5}$, Bishnu Prasad Bhattarai ${ }^{1}$ and Binayak Prasad Rajbhandari ${ }^{1}$ \\ ${ }^{1}$ Himalayan College of Agricultural Science and Technology, Purbanchal University, Kritipur, \\ Kathmandu, Nepal \\ ${ }^{2}$ Institute of Agriculture and Animal Science, Gokuleshwor College, Tribhuvan University, Baitadi, \\ Nepal \\ ${ }^{3}$ Central Department of Chemistry, Tribhuvan University, Kirtipur, Kathmandu, Nepal \\ ${ }^{4}$ Nepal Agricultural Research Council, National Plant Breeding and Genetics Research Centre, \\ Khumaltar, Lalitpur, Nepal \\ ${ }^{5}$ Ministry of Forests and Environment, Government of Nepal, Singha Durbar, Kathmandu, Nepal \\ *Correspondence: agri.kabita35@gmail.com \\ ORCID: https://orcid.org/0000-0002-8852-6749
}

Received: August 12, 2020; Accepted: October 01, 2020; Published: October 30, 2020

(C) Copyright: Tiwari et al. (2020)

(c) (1) This work is licensed under a Creative Commons Attribution-NonCommercial 4.0 International License.

\begin{abstract}
Postharvest loss is one of the major problems in tomato production. This study was conducted to assess the postharvest practices and losses of tomato at the farmers' fields in three districts namely Kathmandu (Kavresthali), Lalitpur (Lubhoo, and Lamatar), and Bhaktapur (Tathali and Kaushaltar). By using a simple random sampling method, the sample size of 60 respondents was chosen. A pre-tested questionnaire, group conversation, and keyinformant survey were applied in this study. The results revealed that $10.3 \%$ of the respondents produced the tomato on a small scale whereas $58.8 \%$ of respondents produced on large scale. $10 \%$ of total losses were found from harvesting to marketing. In the field, during harvesting and packaging, there was a $2 \%$ loss. The tomato loss was negligible during grading and washing. $4 \%$ loss was found during the transportation of tomato and $2 \%$ of the loss during the storage of tomato. To the producer level, the insufficient knowledge about the storage, packaging, transportation, and random harvesting led to the maximum loss of tomato. In the study area, the producers played important role in reducing the postharvest loss of tomato, therefore, public awareness should be increased through mass media about the proper harvesting and storing of tomato.
\end{abstract}

Keywords: Kathmandu valley, packaging and transportation, post-harvest loss, tomato, storage

Correct citation: Tiwari, I., Shah, K.K., Tripathi, S., Modi, B., Shrestha, J., Pandey, H.P., Bhattarai, B.P., \& Rajbhandari, B. P. (2020). Study on post-harvest loss on tomato in Kathmandu valley. Journal of Agriculture and Natural Resources, 3(2), 335-352. DOI: https://doi.org/10.3126/janr.v3i2.32545

\section{INTRODUCTION}

Tomato (Solanum lycopersicum) is the most popular home garden and the world's second most consumed vegetable (Solanum tuberosum) after potato (Ebert, 2020). The species is 
Journal of Agriculture and Natural Resources (2020) 3(2): 335-352

ISSN: 2661-6270 (Print), ISSN: 2661-6289 (Online)

DOI: https://doi.org/10.3126/janr.v3i2.32545

native to Peru and Ecuador, possibly South America, but was first domesticated in Mexico (Benton, 2007). In various ways, such as preserving the ecosystem, providing food, shelter, etc., plants are important to human beings (Modi, 2019). Tomato is known as the world's most widely grown and processed vegetable (FAOSTAT, 2017). China, India, the United States of America, Turkey, and Egypt are the five leading tomato producers in the world. The worldwide production of tomatoes in 2014 was also 171 million tonnes with an average yield of $37 \mathrm{t} / \mathrm{ha}$ (Melomey et al., 2020). In Nepal, the area under tomato cultivation is around 21,981 ha with a total production of $410,721 \mathrm{mt}$ and it has a yield of $19 \mathrm{mt} / \mathrm{ha}$. In the Bhaktapur district, tomato production is $4908 \mathrm{mt}$ in the area of 239 ha land and productivity is $21 \mathrm{mt} / \mathrm{ha}$. In the Kathmandu district, tomato production is $5656 \mathrm{mt}$ in the area of $352 \mathrm{ha}$ land and productivity is $16 \mathrm{mt} / \mathrm{ha}$. In the Lalitpur district, tomato production is $7141 \mathrm{mt}$ in the area of 623ha land with a productivity of $11 \mathrm{mt} / \mathrm{ha}$ (MOALD, 2017/ 18).

A large amount of tomato is not reaching the consumer particularly due to postharvest losses. Postharvest losses can be due to many variables, but in most developing countries, improper handling, packaging, low-level technology, lack of basic equipment and facilities at collection centers, and lack of qualified workers are prevalent. In Nepal, each area has different production technologies and storage conditions, and several production pockets are located away from the market centers. Consequently, post-harvest losses are caused by various horticultural crops and development regions (Bhattarai \& Gautam, 2012). Fresh fruits and vegetables, including tomatoes, are projected to have post-harvest losses of 5 to 25 percent in developed countries and 20-50\% in developing countries (Kader et al., 1985). Fruits and vegetable losses in developed countries vary from 20-50\% during post-harvest cycles (Kader, 1992). Postharvest technology is used in the manufacture, preservation, manufacture, packaging, distribution marketing, improper handling, packaging. Any change in the amount or quality of any after-harvest product that prevents or reduces the intended consumption of the product or decreases its value is a post-harvest loss (Kiaya, 2014). In developing and under-developing countries the losses are more due to lack of proper storage and transport facilities. Acceleration of deterioration can be due to high temperature, low humidity, incorrect atmosphere, and physical damage in the transportation process as well as in storage (Gorny, 2001). After production, management, collection, storage, packaging, transport, and marketing are part of the post-harvest activities (Mrema \& Rolle, 2002). Tomato is the most perishable product in the vegetable group has a considerable amount of losses post-harvest.

Tomato has limited marketability because of its high moisture content and a high degree of perishability that leads to extensive postharvest losses. In Nepal, there is about $30-33 \%$ of post-harvest losses of total production on tomatoes. It is very difficult to increase a $10 \%$ yield but easy to reduce $10 \%$ loss without bringing additional land for production (Gautam \& Bhattarai, 2006). The factors of losses in tomato production after harvest can be separated into two key categories. They are caused both on and off-farm. Incomplete harvest, excessive field rain, inadequate storage of drums, bad agricultural hygiene, and inappropriate packing materials are the causes of farm losses. Off-farm losses have been exacerbated by a shortage of road connectivity, an inadequate distribution network, a shortage of production facilities, and a lack of accurate market knowledge. It is an important issue to study different aspects of tomato production scientifically for further improvement in tomato production in the country. Conservative loss estimates were $25 \%$ for vegetables, $20 \%$ for fruit, and $32 \%$ for potatoes 
Journal of Agriculture and Natural Resources (2020) 3(2): 335-352

ISSN: 2661-6270 (Print), ISSN: 2661-6289 (Online)

DOI: https://doi.org/10.3126/janr.v3i2.32545

according to the tuber seed, according to the master plan for horticultural development (MPHD, 1991). The post-harvest shelf time of horticultural products depends on the state of production, season, variety, harvest stage, harvest method and packaging, transportation, and marketing system developing countries, post-harvest losses of vegetables range from $20 \%$ to $50 \%$ (Kader, 1992). Around 20-50\% of tomato fruit harvested for consumption has been estimated to be wasted due to microbial spoilage and other damage incurred during transit by volatile stresses, rough loading, and unloading (Aworth, 1985).

A major issue in the post-harvest chain is agricultural product losses. They can be triggered by a broad number of causes, ranging from growing conditions to retail handling. Not only is the deficit evidently a food waste, but it is also a significant waste of human efforts, farm inputs, and scarce resources. The objectives of the study were to identify the post-harvest practices of tomato production as well as the factors responsible for post-harvest losses in the Kathmandu valley of Nepal.

\section{METHODOLOGY}

\section{Description of the study area}

The study was conducted in three districts namely Kathmandu (Kavresthali), Lalitpur (Lubhoo and Lamatar), and Bhaktapur (Tathali and Kaushaltar), which are located in Bagmati Pradesh of Province no. 3. Kathmandu is located at $27.6667^{\circ} \mathrm{N}$ and $85.3500^{\circ} \mathrm{E}$ and has an altitude of $1400 \mathrm{~m}$ (4600ft). Kathmandu is a very suitable place for Tomato production. Lalitpur is located at $27.6588^{\circ} \mathrm{N}, 85.3247^{\circ} \mathrm{E}$. The estimated total cultivated land is 14,000 hectares (ha), $48 \%$ of which is irrigated and the remaining is rain-fed. Bhaktapur is located at $27.6710^{\circ} \mathrm{N}, 85.4298^{\circ} \mathrm{E}$. The varied topographic and climatic characteristics conditions in Nepal permit the successful production of a large number of vegetables. Sandy loam soil with humus which appears conducive to the production of vegetables. There is a suitable climate for Tomato production especially after the rainy season; however, off-season production of tomato can also be seen in most parts of the district. Most of the people in the Kathmandu valley are engaged in Tomato production.

\section{Sampling and data collection method}

A total of 60 households from the total respondents were computed by simple random sampling methodology as the sample size for the study area. The study was conducted and completed mainly by collecting primary data and supported by secondary data to some extent. Primary data from the field survey is gathered. The secondary data were collected by reviewing various published and unpublished documents related to the topic of the study. For primary data collection, a household survey was conducted with the help of a semi-structured questionnaire. In a survey, questions were explained in the Nepali language when required because the majority of respondents were illiterate or merely literate. The research was articulated to these respondents through personal correspondence. A set of semi-structured questionnaires was prepared to capture the information related to postharvest losses of Tomatoes, postharvest practices, a different mode of transportation, and packaging and harvesting methods. Besides this, the general information about the respondents and their household like sex, education level, age, etc. were also included in the questionnaire to know the socio-economic condition of the respondent which was used for collecting the actual primary data. To understand the views on post-harvest practices in the community qualitative 
Journal of Agriculture and Natural Resources (2020) 3(2): 335-352

ISSN: 2661-6270 (Print), ISSN: 2661-6289 (Online)

DOI: https://doi.org/10.3126/janr.v3i2.32545

information was also collected. Different secondary information was obtained from the publication of the District Agriculture Development Office (DADO) and the regional and central level Organizations such as the Central Bureau of Statistics Office (CBS), Market research and statistics management program (MRSMP), Ministry of Agriculture, and Livestock Development (MoAD), and Kalimati Fruit and Vegetable Wholesale Market (KFVWM). Information was also collected from published and unpublished literature such as annual reports, research papers, articles, and books.

\section{Data analysis}

The raw data from the survey questionnaire were re-coded, organized, and analyzed using Microsoft Excel 2007. The data obtained were presented in a bar diagram, pie charts, Tables, and graphs. The data were converted into the standard unit, such as land into ropani, weight into kilograms $(\mathrm{kg})$. The results were comprehended logically and the appropriate conclusions were drawn. Therefore, to transform raw data into qualitative findings descriptive statistical tools like; mean, percentage (\%) was used for data analysis. The tomato postharvest losses were estimated using the below formula;

Tomato postharvest losses $=\left(\frac{\mathrm{Wdt}}{\mathrm{Wdt}+\mathrm{Wgt}}\right) \times 100$

Where,

$\mathrm{Wdt}=$ weight of discarded and damaged tomatoes

Wgt $=$ weight of good quality tomatoes obtained after sorting a lot during any stage of handling.

\section{RESULTS AND DISCUSSION}

\section{Socio-economic characteristics of respondents \\ Gender of respondents}

From the survey, it was found that both males and females were found to be involved in tomato production activities and marketing in the study area but the participation of females was lesser than male. It was found that the majority of the respondent $60 \%$ were male and $40 \%$ were female. Other females were engaged in household works and males were engaged in skilled works. The participation of female respondents involved in tomato production was lesser because the female had to do household works such as kitchen, rearing children, etc. Mostly, females were involved in intercultural operation during the cultivation of vegetables i.e. Land preparation, weeding, harvesting, etc. Research has shown that in addition to their daily domestic work, $43 \%$ of women engage in agricultural activities and close to $15 \%$ in agriculture (Shelly \& Costa, 2001) as their second career. In mainstream agricultural and economic research and policies, women's significant efforts are still undervalued, while men's participation remains the key topic, frequently sole topic (Jiggins et al., 1998; Fabiyi et al., 2007).

\section{Table 1. Gender of respondents}

\begin{tabular}{lll}
\hline Gender & Frequency & $\%$ \\
\hline Male & 36 & 60 \\
Female & 24 & 40 \\
Total & 60 & 100 \\
\hline
\end{tabular}




\section{Age of the respondents}

Based on age, the highest number of respondents fall in the age group within 20-40 years age group $(61.1 \%)$, followed by the age group within $40-60$ years age group $(26.6 \%)$ while the lowest in the age group of above 60 years $(12.3 \%)$. None of the respondents was below 20 years of age because most of the young generation were involved in school or colleges and above 60 years were physically weak working in the field. Similarly, Tang and MacLeod (2006) indicated that older employees are on average less productive than younger workers; and that a slightly detrimental effect on productivity growth is a result of the aging labor force. Moreover, a similar result was analyzed by Yang et al. (2011), the effect of the aging of agricultural labor on farmland production, and concluded that the households with mostly young labor have a lower performance in land use than in the households where work is primarily performed by older people.

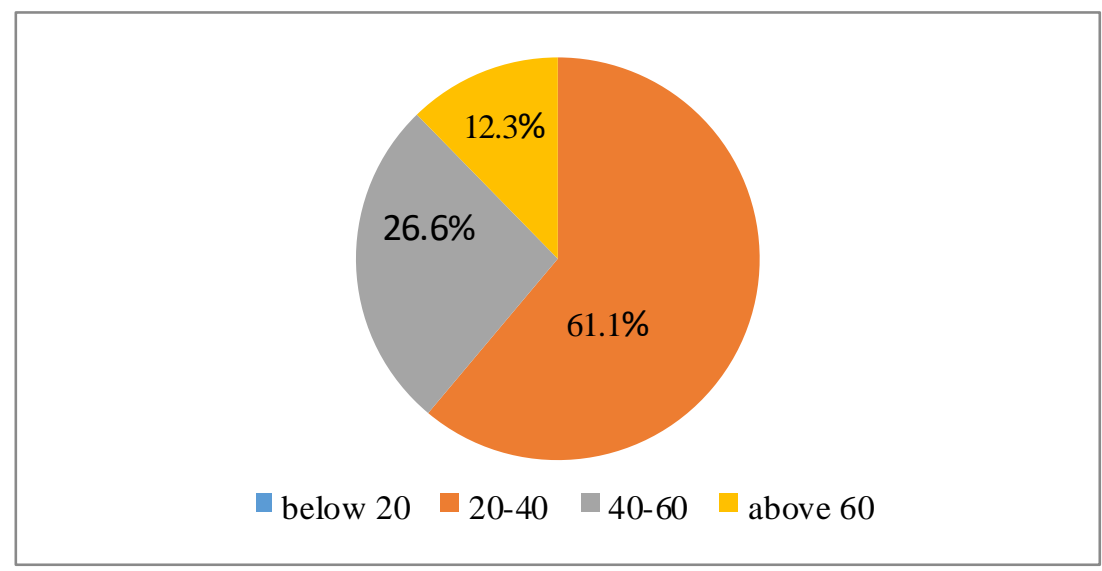

Figure 1. Age of the respondents

\section{Literacy status of respondents}

During the survey, it was found that out of 60 respondents, 42 respondents were illiterate and 18 respondents were literate i.e. $70 \%$ and $30 \%$ were illiterate and literate respectively. Central Bureau of Statistics (CBS, 2011) reported that $33.48 \%$ of the populations were illiterates while just $7.11 \%$ of the population has completed eleven classes on the headcount index. The literate respondents were further categorized under different groups according to their educational attainment. Out of total literacy respondents, only $18 \%$ were educated higher level (higher secondary i.e. college level), the majority of the respondents $45 \%$ reached a primary level, $37 \%$ of the respondents up to secondary level. 


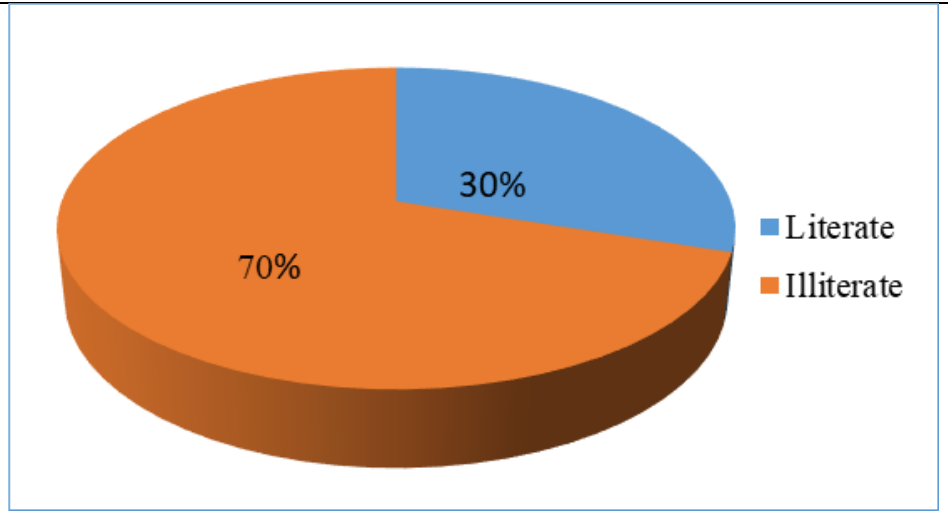

Figure 2. Literacy status of the respondents

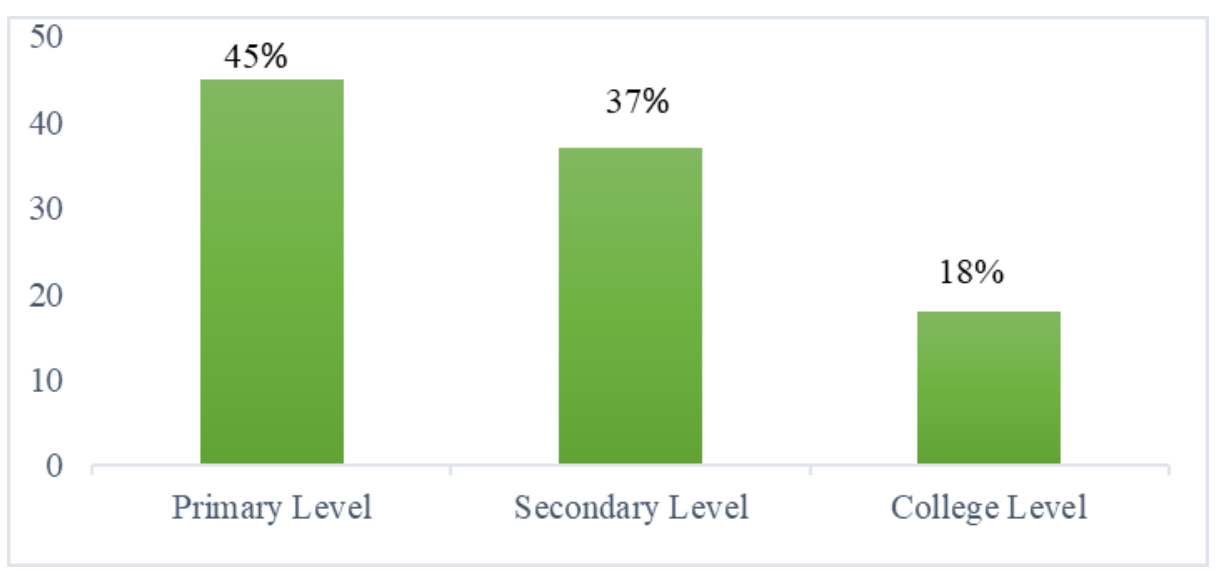

Figure 3. Literacy status of the respondents

Out of the total literacy, few farmers were found to be educated up to a higher secondary level and maximum farmers were educated the only up to the primary level. This is because most of the respondents did not have money to pay the school fee and buy school stationery materials so they stopped their study. Return of farm productivity education range from basic, secondary and tertiary levels with the highest primary education returns (Lockheed et al., 1980; Appleton \& Balihuta, 1996).

\section{The prime occupation of respondents}

Respondents in the study have been involved mainly in agriculture. An agriculture sector that contributes about $36 \%$ of the country's GDP and employs $66 \%$ of its employees is crucial to Nepalese livelihoods (MoAC, 2007). The majority of the respondents in the study area 65\% were involved in agriculture and the other $27 \%$ were found to be involved in both agriculture and business-like small shop, small vegetable collecting center, etc. and only $8 \%$ were doing other services like a driver, Labor, etc. Therefore the tomato farming appeared as a not only very important occupation but also the main of the respondent in the study area. This kind of result was found because most of the respondents were undereducated, suffering from poverty, surveyed areas showed a lack of any employment opportunity, so, they were dependent on agriculture to sustain their lives. 
Journal of Agriculture and Natural Resources (2020) 3(2): 335-352

ISSN: 2661-6270 (Print), ISSN: 2661-6289 (Online)

DOI: https://doi.org/10.3126/janr.v3i2.32545

Table 2. The main occupation of respondents

\begin{tabular}{lll}
\hline Occupation & Frequency & $\%$ \\
\hline Agriculture & 39 & 65 \\
Agriculture and business & 16 & 27 \\
Others & 5 & 8 \\
Total & 60 & 100 \\
\hline
\end{tabular}

\section{Tomato cultivation area of respondents}

Out of 60 respondents, who were farmers were engaged in tomato cultivation. The landholding size of respondent farmers on Tomato production was ranged from 1 or more than 5 Ropani. The percentage of respondents having a total landholding of 1-2 ropani on tomato production was $13 \%$. Those respondents having total landholding $2-5$ ropani was $27 \%$ and the respondents having land more than 5 ropani was $60 \%$. This suggests that producers have more potential in cultivating more tomatoes in their available fields, which will contribute to their commercial production shortly.

Table 3. The area under tomato production

\begin{tabular}{lll}
\hline Size of area (ropani) & Frequency & $\%$ \\
\hline $1-2$ & 8 & 13 \\
$2-5$ & 16 & 27 \\
5 above & 36 & 60 \\
Total & 60 & 100 \\
\hline
\end{tabular}

\section{Tomato varieties preferences}

In the survey, it was found that almost all the respondents didn't cultivate local variety for commercial purposes. Improving range, using fertilizers wisely, and irrigating with effective management methods helps to improve production (Shrestha et al., 2020a). The most popular variety among the respondents found was the Srijana variety (Nepali F1) which was a registered variety, according to the farmers this variety had very high market demand and does not rot faster than other variety. In the surveyed area, almost all farmers used to cultivate Srijana. Srijana, Nepal's first hybrid was planned in terms of efficiency and resistance to bacterial wilt and late blight by the Horticulture Research Division (HRD), 2014 (HRD, 2014). Studies show that the popularity and demand of the variety of Srijana have risen among farmers following the production of the Srijana variety (Magar et al., 2016). To produce the appropriate hybrids for the given domain, we need to produce promising hybrids and continuous variety evaluation (Chapagain et al., 2011). Therefore, no other varieties were seen during the survey period.

\section{Annual tomato production}

Field information showed that out of 60 respondents of a farmer, 8 respondents produce 5150 $\mathrm{kg}$ in an average of tomato in a year. 16 respondents produce $15450 \mathrm{~kg}$ and 36 respondents produce $29400 \mathrm{~kg}$ on average in a year. This production is based on the area of land (ropani). The farmers whose tomato productions were less than $1000-10,000 \mathrm{~kg} / \mathrm{per}$ year were considered as small scale producers, $11000-20,000 \mathrm{~kg}$ were moderate producer and 21000 $30000 \mathrm{~kg}$ were considered a large scale producer. Field information showed that $10.3 \%$ of the farmer was small scale producer in terms of volume of production and $30.9 \%$ of the farmers were moderate scale producer whereas $58.8 \%$ were large scale producer. 
Journal of Agriculture and Natural Resources (2020) 3(2): 335-352

ISSN: 2661-6270 (Print), ISSN: 2661-6289 (Online)

DOI: https://doi.org/10.3126/janr.v3i2.32545

Table 4. Distribution of respondents according to their volume of production in a year

\begin{tabular}{lll}
\hline Range of production & $\begin{array}{l}\text { Production } \\
(\mathrm{kg} / \text { year })\end{array}$ & $\%$ \\
\hline Small scale $(1000-10,000) \mathrm{kg}$ & 5150 & 10.3 \\
Moderate scale $(11000-20000) \mathrm{kg}$ & 15450 & 30.9 \\
Large Scale $(21000-30000) \mathrm{kg}$ & 29400 & 58.8 \\
Total & 50,000 & 100 \\
\hline
\end{tabular}

\section{Harvesting stage of tomato}

Maturity indices are the sign or indication of the readiness of the crops for harvest. Tomato maturity is related to quantifiable parameters, including firmness and color, which represent biochemical changes during ripening according to Zhang and McCarthy (2012). Inadequate nutrient implementation leads to sluggish growth, thin roots, shorter maturity, delayed plant maturation (Pandey et al. 2020). Premature harvesting results in poor quality and deterioration at a faster rate than harvested at the proper stage of maturity. Maturity indices play a vital role in Post-harvest losses of tomato. It was observed during the survey, that in the study area all respondents reported that the maturity indices of tomatoes were the color of the fruits.

Any fruit's physiological maturity during harvest has a major impact on the consistency of the fruit after harvest (Beckles, 2012). Therefore, caution must be taken as the fruit is harvested to produce the highest consistency. Post-harvest physiologists define the shelf-life of fruits and greens in three phases: maturation, ripening, and senescence. The fruit is fit for harvest in the maturation stage (FAO, 2008). Harvesting of the tomato crop at an appropriate stage of maturity is important for long term storage and transport to the distant market. Tomato harvesting at premature or over-mature stage reduce quality and shorten shelf life. The stage of the harvest is shown in figure 4 where $25 \%$ of respondents harvest their produce when soft ripe. $31 \%$ harvest at the mature green stage and $41 \%$ of respondents harvested at the hard ripe stage and $28 \%$ of respondents harvest at the pink stage. Early-ripening tomatoes can shrivel and mechanically harm and they develop poor flavor and taste, despite their durability (Mattheis \& Fellman, 1999; Beckles, 2012). The harvest in gradual maturity yields fruits that taste fine but are short-lived and not suitable for long-distance transport (Dadzie \& Orchard, 1997). The maximum percentage of farmer harvested tomato at the hard ripe stage because it was the preference of the local consumers and it can be stored for a longer period and have a long shelf life and farmer nearby market harvest at the pink as they don't have to wait for the consumer for long time and farmer who are far from market area harvest in the mature green stage because they have to wait for one night for the vehicle to come and pick up their produce for markets, Kalimati and Balkhu. Therefore, the early harvest is suitable for the distant market located at Kalimati and Balkhu, and late harvest id did to the local market to minimize post-harvest loss. Similarly, the losses in tomatoes in the harvest season ranged between 5.15 and $9.83 \%$ in two separate tests in the districts Ayaand and Nallhan in Ankara. It was noted that prevention by producers until their harvest is not adequate, and steps required for decreasing or eliminating the losses also should be taken during harvesting and after collection time (Tatlidil et al., 2003). 


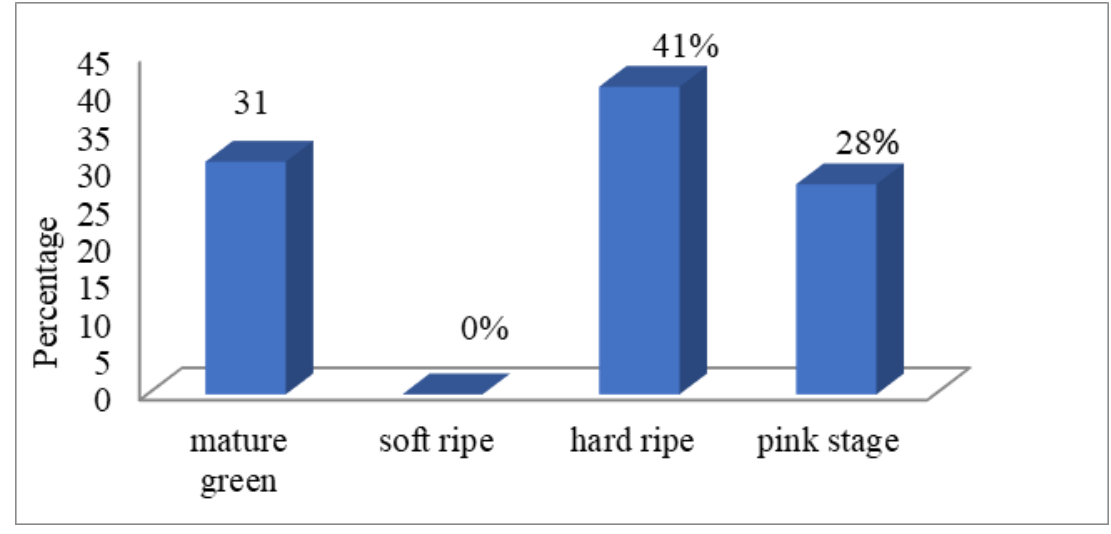

Figure 4. Stage of harvesting

Tomatoes are typically picked in distant markets and processed at a breaking point for local markets, as the correct maturity of the crop influences the storage and quality of the consumer's produce and produce acceptance (Dadzie \& Orchard, 1997). Tomatoes picked later than their ripening green texture will be less susceptible than in premature or partially ripening phases to water loss due to their highly-developed cuticles (Kader, 1984). Therefore, farmers should schedule their harvests to ensure quality and positive market values, followed by proper handling and packaging of fruits (Rajkumar et al., 2012).

\section{Post-harvest operation of tomato adopted by respondents}

Losses from post-harvest are a big problem in most developed countries to impede tomato production (Arah, 2015). Mechanical stress damage is one of the leading causes of postharvest loss in the world (FAO, 1989). Mechanical injuries can contribute to the presence of normal, external, or internal symptoms, causing metabolic and physiological changes in the tomato (Fluck \& Halsey, 1973). As a result of the high humidity, tomatoes have a short life of around 48 hours under tropical conditions (Muhammad et al., 2011). The shelf life of the crop after harvest is therefore required for specific post-care maintenance during harvesting and treatment procedures. The producer from Province no. 3 takes special care for the postharvest loss as the majority of people know total production loss if they don't establish proper care for easily perishable products i.e. Tomato. Post-harvest technologies greatly influence the level of Post-harvest losses and the quality of produce. These include grading, packaging, storage, and transportation that are discussed below.

\section{Cleaning of tomato}

Both producers are concerned not only with post-harvest diseases but also about the prevalence of foodborne diseases transmissible to customers with good hygiene. Different disinfectants are well-documented during the Post-harvest preparation of tomatoes to decrease the occurrence of fungal infection before any postharvest procedure, the sodium hypochlorite solution has been used for the procedure of tomato fruits for example (Genanew, 2013). Tomato fruit dip in a solution for thiabendazole decreased the plant microbial load (Batu \& Thompson, 1998). After cleaning, fruit and vegetables are usually prepared with chlorinated water to reduce the microbial load before processing. (Workneh et al., 2012) 
Journal of Agriculture and Natural Resources (2020) 3(2): 335-352

ISSN: 2661-6270 (Print), ISSN: 2661-6289 (Online)

DOI: https://doi.org/10.3126/janr.v3i2.32545

suggest that the disinfection of tomatoes by anolyte water decreases the microbial fruit loads and thus preserves superior tomato production during storage.

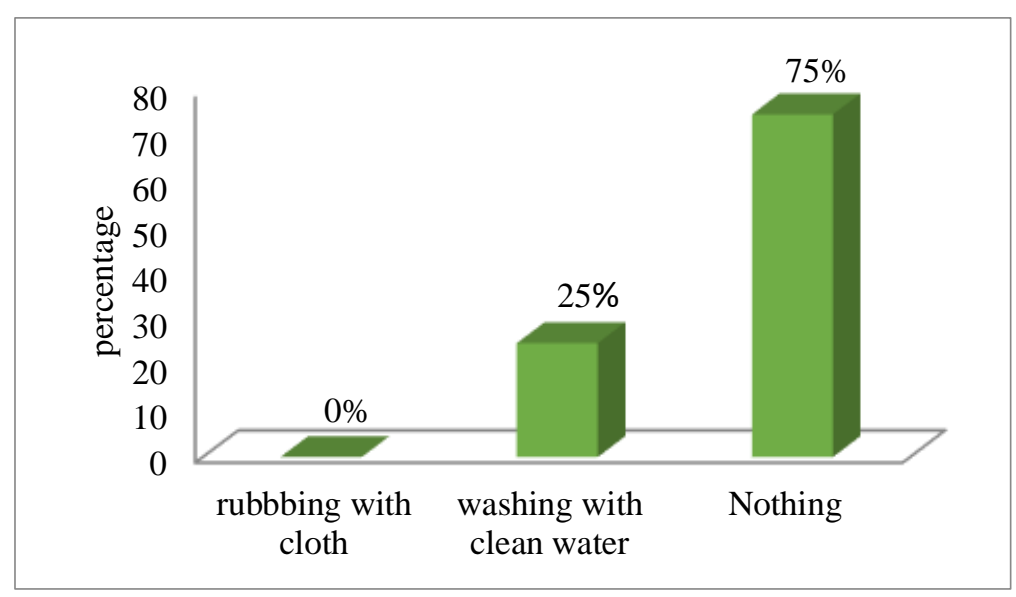

Figure 5. Cleaning of tomato

Based on survey findings, the methods of cleaning of tomato by the respondent were different. The majority of the respondents $75 \%$ did not clean the tomato after harvest the tomato, and none of the respondents rubbed with a cloth after harvest for cleaning purposes. About $25 \%$ of the total respondent cleaned tomato with clean water after harvest. Therefore, the majority of respondents did not clean the tomato because of a lack of knowledge of proper cleaning and application of different disinfectants used for cleaning. Whereas, a very few $25 \%$ were concerned about the cleaning process and used water as cleaning.

\section{Sorting and grading}

Sorting and grading (Arjenaki et al., 2013) are among the main processes in the processing and selling of fruits and vegetables. Sorting involves separating the good and clean from the rotting, affected, or diseased fruits. The infected or malignant fruits will create ethylene in large quantities that can harm the adjacent fruit (Saltveit, 1999). Proper grading is required for the effective marketing of the vegetables. In practice that general level and proportions of fruit and vegetable marketed in modern markets. The process of grading of horticulture produce in Nepal has not progressed much due to the lack of effective extension services for the dissemination of improved postharvest technologies. Less developed market guidelines may not be implemented, but the items are to an extent sorted and sized. Table 6 demonstrates the findings that neither of the farmers had pursued the proper grading of the tomato production obtained. Followers mean the farmers who follow or do the process of grading and sorting and non- followers do not practice these processes of Grading and sorting. From the survey, it was found that almost all producers didn't follow the grading and sorting method. In their perspective, they are usually provided with the market price so it was not necessary for them. Therefore, almost every production did not think of sorting and grading as the reason for the post-harvest loss. 
Journal of Agriculture and Natural Resources (2020) 3(2): 335-352

ISSN: 2661-6270 (Print), ISSN: 2661-6289 (Online)

DOI: https://doi.org/10.3126/janr.v3i2.32545

Table 5. Frequency of respondents that grading with followers of non-followers

\begin{tabular}{lll}
\hline Grading & Frequency & $\%$ \\
\hline Followers & 0 & 0 \\
Non-followers & 60 & 100 \\
Total & 60 & 100 \\
\hline
\end{tabular}

\section{Packaging}

Food products are enclosed to protect the commodity from mechanical disruption, exploitation, and pollution from physical, chemical, or biological sources (Prasad \& Kochhar, 2014). Overloading during collection can cause fruit crushing at the bottom of the containers in the form of excessive compression (Hurst, 2010). The use of flat surfaces and shallow containers to stop overloads would minimize both mechanical injury and the shredding of the fruit harvested. Therefore, Kitinoja (2008) recommended the use of plastic tomato baskets. In the production of tomatoes, it is necessary to pack the products into significant sections for easy handling as a post-harvest process. However, the use of improper packaging will lead to a loss of fruit damage (Idah et al., 2007). There are different modes of packaging. Generally, container-packaging is considered ideal for packing vegetables because these are easy to handle, provide good protection from mechanical damage, and have adequate ventilation. After preparation and packing, the minimum consistency criteria for Tomatoes include: intact, fresh-looking, sterile, without unnecessary moisture, sound, and free from any natural scent and/or taste (Sargent \& Moretti, 2002). High quality, standard, and vibrant fruit without any signs of fracture, shriveling, or decay (Sargent \& Moretti, 2002) are the fruit of excellent quality. Tomatoes must also be packaged to be fully secured. The result is shown in figure 6 . It is indicated that the majority of the respondent in the sampled area nowadays used plastic crates and some respondents used Bamboo baskets (DOKO) for packing and transporting their produce to the whether supplied in a local or wholesale market.

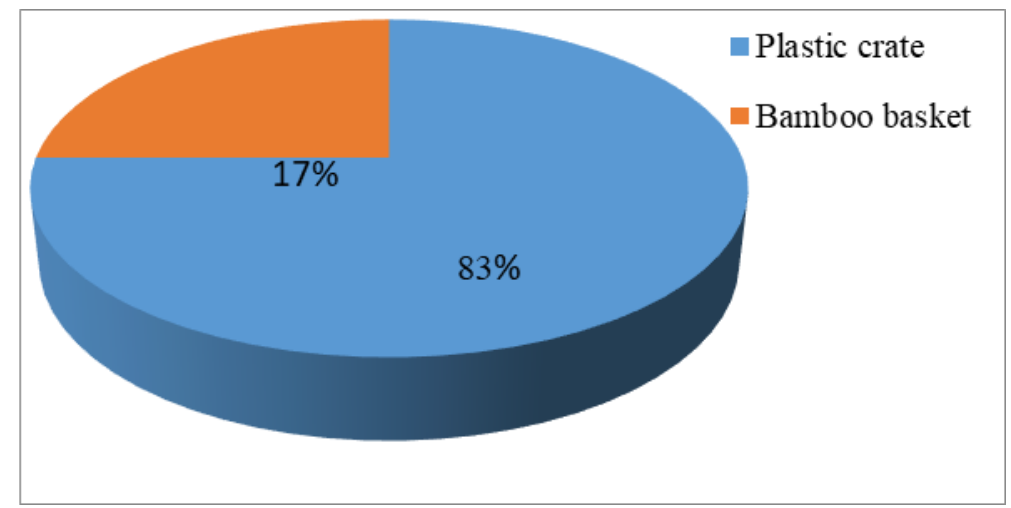

Figure 6. Packaging

\section{Storage}

Tomato is highly perishable. So, storage is needed to extend the marketing period. The function of the storage is to provide an environment, which minimizes the deterioration until it is finally consumed. Tomato fruit can be preserved in the atmosphere (Znidarcic \& Pozrl, 2006) for short-term storage (by a single week) where adequate ventilation occurs to minimize heat accumulation from respiration. Ripened tomatoes can be preserved at around 
Journal of Agriculture and Natural Resources (2020) 3(2): 335-352

ISSN: 2661-6270 (Print), ISSN: 2661-6289 (Online)

DOI: https://doi.org/10.3126/janr.v3i2.32545

$10-15{ }^{\circ} \mathrm{C}$ and relative humidity of $85 \%-95 \%$ for long-term storage (Castro et al., 2005). Proper temperature and humidity management are very effective tools in ensuring the product remains in good condition throughout the storage. Effective temperature, moisture, and air quality monitors optimize the product's product existence. In the study area, there is no method of storage because of the unavailability of storage facilities and the lack of basic knowledge of the practices. Local people have indigenous knowledge for the storage of agricultural products for future use (Shrestha et al., 2020). The only way by which some of the farmers stored their produce is by covering it with plastic or doko. However, this could only last for one day before they are taken to the market for sale. According to the respondents of the surveyed area, there were no facilities of storage for highly perishable vegetables. So, the entire farmer harvested tomato, and the next day or on the same day they took tomato in the market. Therefore, when there was a political strike or road strike, due to the unavailability of storage facilities there was a huge loss of fresh tomatoes every year reported by the respondent.

\section{Mode of transportation}

In Nepal, there are very significant losses of tomato fruit during transport from the processing area to the marketplace. The survey resulted in the loss during transportation was $4 \%$ in different districts of nearly $25 \mathrm{~km}$ short distance. These losses were mainly physical losses which occurred due to bumping of road and vehicles while traveling from one place to another. Similarly, the total loss of tomato fruit in transportation over a distance of $73 \mathrm{~km}$ from the site to Pokhara was recorded to be $16 \%$ losses during transportation, which were significantly different depending on the maturity of the fruit harvested at the mature green stage, with the $(5.3 \%)$ lowest loss (Devkota et al., 2014). At the pink and full red stage, the loss was 19.3 and 24\%, respectively. The products must be appropriately wrapped and stored during shipment to discourage unwanted movement or vibration. Vibration during transportation may cause bruising or their type of mechanical injury (Chesson \& O'Brien, 1971)Tomato transport to the market on such rough roads and the availability of appropriate transport facilities such as chilled vans are becoming a major problem for farmers and distributors (Abimbola, 2014). Study shows that, a different mode of transportation used by the area farmers for tomato marketing. The farmer $87 \%$ transported their product in vehicles like trucks, tractors, buses, etc, while the remaining transport their product on their back by using locally available material (Doko) to the near market. According to the respondents, traders from the Kalimati and Balkhu market send their vehicles to the farm and they carry their produce to market. So, they used to say that they don't have to pay a single amount of money for the transportation of their tomatoes to the market.

Table 6. Mode of transportation

\begin{tabular}{lll}
\hline Mode of transportation & Frequency & $\%$ \\
\hline Self Load & 8 & 13 \\
By vehicles & 52 & 87 \\
Total & 60 & 100 \\
\hline
\end{tabular}

\section{Distribution and Marketing}

The market is the place where the exchange of the product between the consumer and the shopkeeper takes place. From the survey it was found that kamal Binayak, Jagati, and Suryabinayak were the main local and wholesale market of Bhaktapur, Lalitpur vegetable 
Journal of Agriculture and Natural Resources (2020) 3(2): 335-352

ISSN: 2661-6270 (Print), ISSN: 2661-6289 (Online)

DOI: https://doi.org/10.3126/janr.v3i2.32545

bazaar was the main wholesale market for Lalitpur district followed by Kalimati and Balkhu wholesale market for Kathmandu district. According to the respondent, $10.67 \%$ of respondents sold their tomato to the local market and the rest of $89.33 \%$ of respondents supply their produce in city areas through cooperatives or traders directly. I.e. in Kalimati and Balkhu market. Therefore, the need for change is illustrated by the fact that in developing countries where there are stills weak infrastructure and the absence of marketing facilities and fruit losses after harvest range from $20 \%$ to $50 \%$ (Gummesson, 1987).

\section{Postharvest and its causes}

Large numbers of growers are concerned with the cultivation of tomatoes but due lack of proper training, cold storages, Poor means of transportation, Lack of post-harvest awareness, and incorrect methods of harvest lead to losses of tomato fruit following harvest. Rough harvesting can cause mechanical accidents during harvest and after harvesting that can impact the consistency of post-harvest and life cycle of harvested fruits such as tomatoes (Deepthi \& Sekhar, 2015). Post-harvest life depends on the rate at which they use up its stored food reserves and its rate of water loss. Tomato declines when food and water have been exhausted (Akhtar et al., 1994; Abou-Aziz et al. 1976; Ait-Oubahou, 1990).

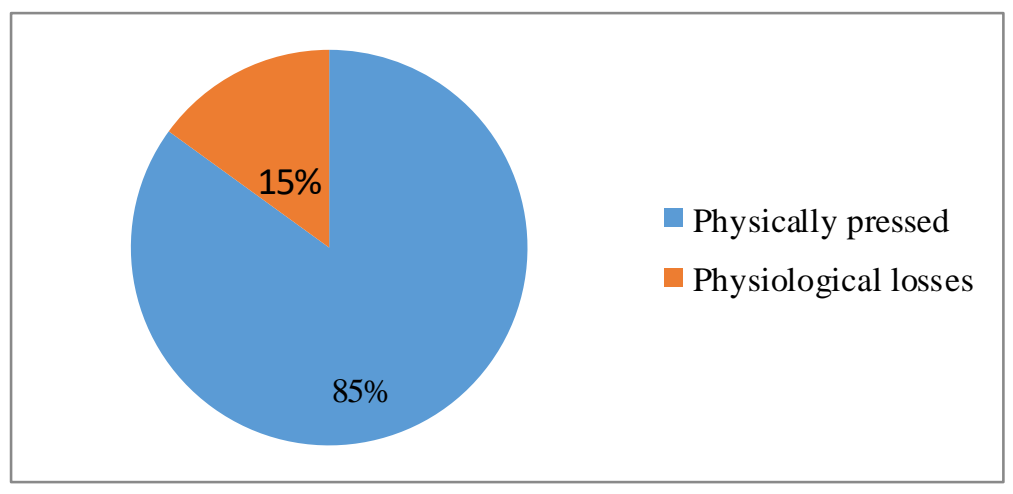

Figure 7. Cause of postharvest loss

During the survey, it was found that all farmers reported the main cause of post-harvest losses of tomatoes during the transportation from the place of production to the market center. Various types of losses have been observed, such as physically pressed losses and physiological losses. During the survey, it was found that the majority of the respondent informed that physically pressed losses including disease and insect pests were highest, in the study area this loss was reported by $85 \%$ of the respondent, whereas only $15 \%$ of respondents reported losses of tomato to physiological changes.

\section{Losses of tomato during the different levels of post-harvest activities.}

Losses are estimated according to the experience of the farmers/respondents. They had different stages of losses from harvesting to marketing. Respondent and DADO did not have any appropriate data of losses during postharvest activities but the finding result was only tentative of farmers. From the survey, it was found that every farmer has a different percentage of losses during post-harvest activities from harvesting to marketing. $10 \%$ of total losses were found from harvesting to marketing, i.e. $2 \%, 2 \%, 4 \%$, and $2 \%$ during harvesting, 
Journal of Agriculture and Natural Resources (2020) 3(2): 335-352

ISSN: 2661-6270 (Print), ISSN: 2661-6289 (Online)

DOI: https://doi.org/10.3126/janr.v3i2.32545

packaging, transportation, and storage respectively. During transportation (4\%) losses was found highest because some of the respondents used traditional bamboo basket as packaging materials which were not appropriate packages during transportation so losses were increased due to physical pressure and also they did not use appropriate harvesting method so losses were increased due to mechanical injury during harvesting.

A total of $10 \%$ loss is obtained from the result of the survey. As it is only the result from a survey of Kathmandu valley, it represents the data from only Kathmandu valley which is also a great loss because Kathmandu valley is the city access to road and another facility. Looking at the road facilities and vehicles it was found that there was a major loss in transportation i.e. $4 \%$. There was a notable problem regarding the loss i.e. there was not a separate vehicle for tomato supply. Due to unbalanced loading and unloading, carelessness in managing products was considered as the major reason for transport loss. Also, many producers lack knowledge on the maturity indices of tomato, harvesting period, methods of the collection which was the major reason for a $2 \%$ loss in harvesting. There was not any specific brand or media where people use for the means of packaging. Normal plastic and DOKO (bamboo basket) were used for packaging media which lead to the major breakage of tomato, further having microbial attack maximum products was wasted.

The causes of losses were due to a lack of packaging materials and vehicles with traders and a smooth road for transportation. Therefore, the unmanaged packaging system was the major reason for the $2 \%$ loss in the products. There was not any loss in the grading, sorting, and cleaning process, as almost every producer was more concerned about the post-harvest loss. Lost during storage of tomato by physiological during storage time, the main reason behind losses during storage was the use of the ordinary room as a storage place. Moreover, maximum losses were due to physical damage and physiological losses due to temperature and pressures seems when the trader did not reach to market in time. The producer did not have separate rooms to collect the product, also did not use any freezer which results in a $2 \%$ loss in production.

Table 7. Loss of tomato during the different level of post-harvest activities

\begin{tabular}{ll}
\hline Post Harvest activities & Loss $(\%)$ \\
\hline Harvesting & 2 \\
Packaging & 2 \\
Transportation & 4 \\
Grading & 0 \\
Cleaning & 0 \\
Storage & 2 \\
\hline
\end{tabular}

\section{CONCLUSIONS}

Estimation of postharvest losses is important as it helps in identifying the causal factors and provides ways and means to reduce the losses. These losses take place at all stages resulting in losses to farmers. In the study area, there was a high level of post-harvest losses on tomatoes in Kathmandu valley, Nepal. These losses were higher in transportation as compared to other factors, there was no method of storage in the area because of the unavailability of storage facilities, and the majority of farmers sold their product in the local market. Producers were not provided with a separate transport system, they were still focused 
Journal of Agriculture and Natural Resources (2020) 3(2): 335-352

ISSN: 2661-6270 (Print), ISSN: 2661-6289 (Online)

DOI: https://doi.org/10.3126/janr.v3i2.32545

on the traditional method of packaging as DOKO and plastic. There was no separate room for storage and have little knowledge of the freezer, maintaining humidity, proper handling, and harvesting. For the higher production of tomato, the farmers of the study area should be provided with appropriate training, technical advice, and support from the government, organization as well as NGOs/INGOs. Research is required for quality production, processing, storage, transport, and handling improvements. Technical help for the development of quality country-wide seeds and production of fresh tomatoes in potentially pockets with little or least use of inorganic chemicals must be given to farmers' groups during off-season vegetable production. This study attempted to identify losses occurring at different levels. Reliable database on loss help to make proper planning for monitoring and controlling of post-harvest losses.

\section{ACKNOWLEDGEMENTS}

The authors are highly grateful to authors feel privileged to thank the Himalayan College of Agricultural Science and Technology (HICAST), Kathmandu, Nepal for providing financial support to carry out this study.

\section{Authors' Contributions}

I. Tiwari and K.K. Shah analyzed, conducted, and prepare the manuscript of the experiment. B. Modi revised the final paper, S. Tripathi helped in the experiment and H.P. Pandey edited whole manuscripts, english checking, and verified the analysis and data presented in the manuscript.B.P. Bhattarai and B.P. Rajbhandari supervised during the experiment. J. Shrestha helped in preparation of figures and edited initial draft of the manuscript.All author approved the final version of this manuscript.

\section{Conflict of interest}

The authors declare no conflicts of interest regarding the publication of this manuscript.

\section{REFERENCES}

Abimbola, O.A. (2014). Post-harvest losses and welfare of tomato farmers in Ogbomosho, Osun state, Nigeria. Journal of Stored Products and Postharvest Research, 5(2), 813.

Abou-Aziz, A.B., El-Nataway, S.M., Adel-Wahab, F.K., \& Kader, A.A. (1976). The effect of storage temperature on quality and decay percentage. Science Horticulture, 5, 65-72.

Ait-Oubahou, A., \& Dilley, D.R. (1990). Design and optimization of modified atmosphere packaging of Empire apple fruit following Controlled Atmosphere Storage. Proceeding of the Congress of the Mediterranean Phytopathologicla Union, Oc. 28Nov3, Agadir, Morocco.

Akhtar, K.P., Matin, M., Mirza, J.H., Shakir, A.S., \& Rafique, M. (1994). Some studies on the postharvest diseases of tomato fruits and their chemical control. Pak. J. Phytopath, $6,125-129$.

Appleton, S., \& Balihuta, A. (1996). Education and Agricultural Productivity: Evidence from Uganda. Journal of International Developement, 8(3), 415-444.

Arah, I.K., Amaglo, H., Kumah, E.K., \& Ofori, H. (2015). Preharvest and postharvest factors affecting the quality and shelf life of harvested tomatoes: a mini review. International Journal of Agronomy. Article ID 478041, 6 pages. 
Journal of Agriculture and Natural Resources (2020) 3(2): 335-352

ISSN: 2661-6270 (Print), ISSN: 2661-6289 (Online)

DOI: https://doi.org/10.3126/janr.v3i2.32545

Arjenaki, O.O., Moghaddam, P.A., \& Motlagh, A.M. (2013). Online tomato sorting based on shape, maturity, size, and surface defects using machine vision. Turkish Journal of Agriculture and Forestry, 37(1), 62-68.

Aworth, O.C. (1985). Preservation of Perishable Food Commodities through Processing, Nigerian Food Journal, 2(3), 24-44.

Batu, A., \& Thompson, A.K. (1998). Effects of modified atmosphere packaging on post harvest qualities of pink tomatoes. Turkish Journal of Agriculture and Forestry, 22(04), 365-372.

Beckles D.M. (2012). Factors affecting the postharvest soluble solids and sugar content of tomato (Solanum lycopersicum L.) fruit. Postharvest Biology and Technology, 63(1), $129-140$.

Benton, J., Jr. (2007). Tomato plant culture: In the field, greenhouse, and home garden. CRC Press, London.

Bhattarai, D.R., \& Gautam, D.M. (2012). Post harvest horticulture, Bhawani printing press, Kathmandu, Nepal.

Bhattarai, D.R., \& Gautam, M. (2006). Effect of harvesting method and Calcium on Postharvest Physiology of Tomato. Nepal Agric. Res. J. 4(7), 37-41.

Castro, L.R., Vigneault, C., Charles, M.T., \& Cortez, L.A.B. (2005). Effect of cooling delay and cold-chain breakage on 'Santa Clara' tomato. Journal of Food, Agriculture \& Environment, 3(1), 49-54.

CBS (Central Bureau of Statistics). (2011). Nepal living standards survey 2010/11. Vol. I. Kathmandu, Nepal.

Chesson, J.H., \& O'Brien, M. (1971). Analysis of Mechanical Vibration of Fruit during Transportation. Transactions of Agricultural Engineering International : The CIGR $e$ journal, 14(2), 0222-0224. doi: 10.13031/2013.38262.

Deepthi, V., \& Sekhar, R. (2015). Post harvest physiological and biochemical changes in guava (cv. LUCKNOW-49) fruits harvested at two stages of maturity during low temperature storage. International journal of processing and post harvest technology, 6(2), 128-143. DOI: 10.15740/has/ijppht/6.2/128-143

Ebert, A. W. (2020). The role of vegetable genetic resources in nutrition security and vegetable breeding. Plants, 9(6), 736. DOI: https://doi.org/10.3390/plants9060736

Fabiyi, E.F., Danladi, B.B., Akande, K.E., \& Mahmood, Y. (2007). Role of Women in Agricultural Development and Their Constraints: A Case Study of Biliri Local Government Area, Gombe State, Nigeria. Pakistan Journal of Nutrition, 6(6), 676-680.

FAO. (1989). Prevention of Post-harvest food losses: Fruits, vegetables and root crops, A Training Manual, Forest Finance Working Paper, 17-20.

FAOSTAT. (2017). Food and Agricultural Organization (FAO). Retrieved August 25, 2019, from Food and Agricultural Organization. Web site: http://www.fao.org/faostat/en/\#data/QC

Fluck, R.C., \& Halsey, L.H. (1973). Impact forces and tomato bruising. Florida Agricultural Experimental Station Journal, 5109, 239-242.

Genanew, T., (2013). Effect of post harvest treatments on storage behavior and quality of tomato fruits. World Journal of Agricultural Sciences, 9(1), 29-37.

Gorny, J.R. (2001). A summary of CA and MA requirements and recommendations for freshcut (minimally processed) fruits and vegetables. Doi: https://doi.org/10.17660/ActaHortic.2003.600.92 
Journal of Agriculture and Natural Resources (2020) 3(2): 335-352

ISSN: 2661-6270 (Print), ISSN: 2661-6289 (Online)

DOI: https://doi.org/10.3126/janr.v3i2.32545

Gummesson, E. (1987). The new marketing- Developing long-term interactive relationships. Long Range Planning, 20(4), 10-20. DOI: 10.1016/0024-6301(87)90151-8.

HRD. (2014). Annual Report. Khumaltar, Lalitpur, Nepal: Horticulture Research Division (HRD).

Idah, P.A., Ajisegiri, E.S.A., \&. Yisa, M.G. (2007). Fruits and vegetables handling and transportation in Nigeria. Assumption University Journal of Technology. 10(3), 175183.

Jiggins, J.R., Samanta, K., \& Olawoye, J.E. (1998). Improving women farmers' access to extension services: Food and Agriculture Organization of United Nations, Rome,73-82.

Kader, A.A. (1984). Effect of postharvest handling procedures on tomato quality. Acta Horticulturae 190: 209- 221.

Kader, A.A. (1992). Modified atmosphere packaging of Fruits and vegetables, CRC Rev. Food Science and Nutrition, 28, 1-30.

Kader, A.A. (1992). Post-harvest technology of horticultural crops. 2nd Ed. Univ. of California, Div. of Agri and Natural Resources. Public, 3311.

Kader, A.A., Kasmire, R.F., Mitchell, F.G., Reid, M.S., Sommer, N.F., \& Thomson, J.F. (1985). Post harvest Technology of Horticultural crops. University of California. Publication. 3311, 192-199.

Kiaya, V. (2014). Post-harvest losses and strategies to reduce them. Technical Paper on Postharvest Losses, Action Contre la Faim (ACF), 25.

Kitinoja, L. \& Gorny, J.2009. Storage Practices and Structures. Postharvest Technology for Fruit and Vegetable Produce Marketers, 7(1), 1-20.

Lockheed, M.E., Jamison, T., \& Lau, L.J. (1980). Farmer Education and Farm Efficiency: A kiSurvey. Economic Development and Cultural Change, 29(1), 37-76.

Magar, D. B., Gauchan, D., Timsina, K. P., \& Ghimire, Y. N. (2016). Srijana Hybrid Tomato: A Potential Technology for Enterprise Development in Nepal. Khumaltar, Lalitpur, Nepal: Socioeconomics \& Agricultural Research Policy Division, Nepal Agricultural Research Council (NARC).

Mattheis, J.P., \& Fellman, J.K. (1999). Preharvest factors affecting flavor of fresh fruit and vegetables. Postharharv. Biol Technology, 15, 227-232.

Melomey, L.D., Danquah, A., Offei, S.K., Ofori, Kwadwo., Danquah, E., \& Osei, M. (2019). Review on Tomato (Solanum lycopersicum, L.) Improvement Programmes in Ghana, Recent Advances in Tomato Breeding and Production, Seloame Tatu Nyaku and Agyemang Danquah, IntechOpen. DOI: 10.5772/intechopen.75843.

MoAC (2007). Statistical Information on Nepalese Agriculture. Government of Nepal, Ministry of Agriculture and Cooperatives, Agri-Business Promotion and Statistics Division, Kathmandu, Nepal.

MOALD, (2017/18). Statistical Information on Nepalese Agriculture. Ministry of Agriculture and Livestock Development, Singha Durbar, Kathmandu, Nepal.

Modi, B. (2019). Phytochemical analysis and nutritional value determination of Tinospora cordifolia. Masters Degree, Tribhuvan University, Kirtipur, Kathmandu, Nepal.

Mrema, C.G., \& Rolle, S.R. (2002). Status of the postharvest sector and its contribution to agricultural development and economic growth. 9th JIRCAS International Symposium- Value Addition to Agricultural Product, 13-20.

Muhammad, R.H., Bamisheyi, E., \& Olayemi, F.F. (2011). The effect of stage of ripening on the shelf life of tomatoes (Lycopersicon esculentum) stored in the evaporative cooling 
Journal of Agriculture and Natural Resources (2020) 3(2): 335-352

ISSN: 2661-6270 (Print), ISSN: 2661-6289 (Online)

DOI: https://doi.org/10.3126/janr.v3i2.32545

system (E.C.S). Journal of Dairying, Foods \& Home Sciences, 30(4), 299-301.

Pandey, M., Shrestha, J., Subedi, S., \& Shah, K. K. (2020). Role of nutrients in wheat (Triticum aestivum L.): A review. Tropical Agro biodiversity, 1(1), 18-23. DOI: https://trab.org.my/archives/1trab2020/1trab2020-18-23.pdf

Prasad, P., \& Kochhar, A. (2014). Active packaging in food industry: a review. Journal of Environmental Science, Toxicology and Food Technology, 8 (5), 1-7.

Rajkumar, P., Wang, N., EImasry, G., Raghavan, G.S.V., \& Gariepy, Y. (2012). Studies on banana fruit quality and maturity stages using hyperspectral imaging. Journal of Food England, 108, 194-200.

Saltveit, M.E. (1999). Effect of ethylene on quality of fresh fruits and vegetables. Postharvest Biology and Technology, 15(3), 279-292.

Sargent, S., \& Moretti, C. (2002). Tomato. In: Gross, K. Wang, C. and Saltveit, M. (eds.). The Commercial Storage of Fruits, Vegetables, and Florist and Nursery Stocks.United States Department of Agriculture Handbook 66.

Shelly, A.B., \& Costa. M.D., (2001). Women in Aquaculture: Initiatives of Caritas. Caritas Fisheries Program, Bangladesh. DOI: http://www.worldfishcenter.org/pubs/wif/wifglobal/wifg-asia-caritaspdf

Shrestha, J., Shah, K.K., \& Timsina, K. (2020a). Effects of different plant fertilizers on growth and productivity of rice (Oryza sativa L.): a review. International Journal of Global Science Research, 7(1), 1291-1301. https://doi.org/10.26540/ijgsr.v7.i1.2020.151

Shrestha, S., Shrestha, J., \& Shah, K.K. (2020). Non- timber Forest Products and their Role in the Livelihoods of People of Nepal: A Critical Reviews. Grassroots Journal of Natural Resources, 3(2), 42-56.DOI: https://doi.org/10.33002/nr2581.6853.03024

Tang J., \& MacLeod, C. (2006). Labour force ageing and productivity performance in Canada. Canadian Journal of Economics, 39(2), 582-603.

Tatlidil, F., Kiral, T., Gunes, A., Demir, K., Erdemir, G., Fidan, H., Demirci, F., Erdogan, C., \& Akturk, D. (2003). Economic Analysis of Crop losses during Pre-Harvest and Harvest Periods in Tomato Production in the Aya and Nallihan Districts of Ankara Province. Scientific Research and Essay, 6(7), 1656- 1666.

Workneh, T.S., Osthoff, G., \& Steyn, M. (2012). Effects of preharvest treatment, disinfections, packaging and storage environment on quality of tomato. Journal of Food Science and Technology, 49(6), 685-694.

Yang, J., Yang, G., \& Hu, X. (2011). Age effects on the agricultural labor force farmers cultivated land use efficiency evidence from different levels of economic development in the region. Resources Science, 9, 1691-1698.

Zhang, L., \& McCarthy, M.J. (2012). Measurement and evaluation of tomato maturity using magnetic resonance imaging. Postharvest Biology and Technology, 67, 37-43.

Znidarcic, D., \& Pozrl, T. (2006). Comparative study of quality changes in tomato cv. Malike (Lycopersicon esculentum Mill) while stored at different temperatures. Acta Agriculturae Slovenica, 87(2), 235-243. 